Bangladesh J. Zool. 49 (1): 83-90, 2021

ISSN: 0304-9027

eISSN: $2408-8455$

\title{
ARTHROSCHISTA HILARALIS: THE BIOLOGY AND EMERGING THREAT TO KADAM (ANTHOCEPHALUS CADAMBA) SAPLING IN SYLHET, BANGLADESH
}

\author{
Md. Mehedi Hasan ${ }^{1}$, H. M. Shamim², Mohammad Ishtiak pabel ${ }^{3}$ \\ and Md. Fuad Mondal ${ }^{1 *}$ \\ Department of Entomology, Sylhet Agricultural University, Sylhet-3100, \\ Bangladesh
}

\begin{abstract}
In Sylhet, nursery owner facing a lepidopteran pest problem namely Arthroschista hilaralis on kadam saplings. Therefore, our research was articulated to find out the insect biology and damage severity of $A$. hilaralis on kadam saplings. Larvae of $A$. hilaralis folding the kadam leaves and make it entirely skeletonize. Whitish round shaped eggs were laid in cluster at both upper and lower surface of kadam leaves. Eggs were hatched after $6.4 \pm 0.2$ days and the larval stage remained $12.8 \pm 0.3$ days which was the main dangerous stage for kadam saplings. The full-grown caterpillars were around $21.5 \mathrm{~mm}$ to $25.0 \mathrm{~mm}$ in length. Pupal stage required around $6.4 \pm 0.6$ days to became an adult moth. These insects damaged tender branches and young leaves of kadam saplings in June to October, 2018.
\end{abstract}

Key word: Kadam (Anthocephalus cadamba), Arthroschista hilaralis, damage status, pest biology

\section{INTRODUCTION}

Anthocephalus cadamba Miq. commonly named Kadam is distributed in South Asia and Southeast Asia, including Indonesia, Thailand and Indo-china and eastward in Malaysian archipelago to Papua New Guinea which belongs to the family Rubiaceae (Budi et al. 2015, Krisnawati et al. 2011, Dubey et al. 2011). This tree is very common from in hill areas of North East Indian states which very near to Sylhet (Gogoi et al. 2015). The standing nature in the marshy lands or waterbody make this forest species popular in Sylhet region of Bangladesh. In Bangladesh its major area of plantation is observed in Sylhet and Chittagong hill tracts (Banglapedia 2015). This deciduous tree's bark is generally used to retain tonic, bitter, pungent, sweet, acrid, astringent, which also given to treatment of fever and inflammation (Gautam et al. 2012, Dubey et al. 2011). The leaves are good for diabetes mellitus, diarrhoea, fever, inflammation, haemoptysis, cough, vomiting, wounds, ulcers, debility and,

* Author for corresponding: <mondalmf.entom@sau.ac.bd>, 2 Department of Agricultural Extension, Dighalia, Khulna-9220, Bangladesh, ${ }^{3}$ Department of Agroforestry and Environmental Science, Sylhet Agricultural University, Sylhet-3100, Bangladesh

(C2021 Zoological Society of Bangladesh DOI: https://doi.org/10.3329/bjz.v49i1.53684 
antimicrobial activity (Alam et al. 2011 Dubey et al. 2011, Alam et al. 2008). A variety of insects often infest the kadam leaves. Some unidentified caterpillar's occurred heavy defoliation in plantations in South and East Kalimantan of Indonesia (Selander 1990, Tangketasik 1987). It has been reported that defoliator (Margaronia sp.) and white grubs eating the leaves and roots of kadam saplings, respectively (Suratmo 1987, Intari and Natawiria 1973). Forest Department, West Bengal, India has been observed young kadam trees suffered severe defoliation damage by some lepidopteran pest which completing 11-12 generations in a year with 21-26 days of life-span in kadam leaves (Thapa and Bhandari 1976). Pest population on Kadam sapling begins to epidemic after rainfall during July-August. (Thapa and Bhandari 1976, Thapa 1970, Baksha 2000). The large-scale incidence and intensity of $A$. hilaralis on kadam reported at the planting age (Utami et al. 2018).

In Bangladesh, major pests which are pernicious for kadam plants are Bengal amond defoliator (Metanastria hyrtaca), teak canker grub (Dihammus cervinus) and kadam defoliator (A. hilaralis), respectively (BFD 2018, Baksha 2000). Recently, nursery owners of Sylhet who supply 3000-3500 kadam saplings (pre surveyed data) are facing a lepidopteran pest problem namely $A$. hilaralis. They are using different insecticides against the infested saplings to recover them. In some nurseries the leaves were severely infested consequently total damage had occurred. Considering the damage severity, there was an urgent need to carry out an experiment on the biology and damage potential of this pest in Sylhet, Bangladesh. Therefore, the research was aimed to find out the infestation level of $A$. hilaralis in different nurseries of Sylhet, Bangladesh and to investigate the biology and nature of damage of $A$. hilaralis in kadam saplings.

\section{MATERIAL AND METHODS}

Field observation: A. hilaralis infestation in kadam saplings were investigated at different nurseries of Sylhet district $\left(24^{\circ} 36^{\prime}\right.$ and $25^{\circ} 11^{\prime}$ north latitudes and in between $91^{\circ} 38^{\prime}$ and 92 $30^{\prime}$ east longitudes) of Bangladesh. It had been categories the major nursery areas into three zone for representing the real scenario these areas were Zindabazar, Khadimnagor, South Surma of Sylhet district. The study was done through survey questionnaire and interview with the relevant respondents (nursery owners) from June 2018 to May 2019. Five nursery owners from each location were interviewed randomly and the level of $A$. hilaralis infestation on A cadamba leaves, number of insects per leaves, and time of infestation were recorded from those nurseries. 
Laboratory Experiment: Laboratory experiment was conducted at the Laboratory of Entomology of Sylhet Agricultural University, Bangladesh to study the biology of $A$. hilaralis in the control conditions during June to October, 2018. Three pairs of adult male and female $A$. hilaralis were kept inside rearing boxes $(77 \times 40 \mathrm{~cm}$; made of transparent plastic boxes) covered by mosquito nets to observe the life cycle. Honey solution was provided for adults. As the adults laid eggs on the leaves therefore small twigs with some leaves were provided. The young kadam twigs were kept in $5 \%$ honey solution inside plastic jar. After hatching eggs cluster were separated and kept inside the petri dishes. Young leaves were provided every day evening for the larvae and observed very carefully until completing its life cycle. Different larval stages were identified carefully by observing the molting of larvae that changed on different instar.

Data Analysis: The collected data of biological stages of A. hilaralis $(n=15)$ and number of leaves infestation/plant were analyzed by Microsoft Office Excel 2013 statistical analysis and A. hilaralis infestation on kadam saplings were analyzed with 5\% level of significant by one-way ANOVA in Statistix 8.1 software package.

\section{RESULTS AND DISCUSSIONS}

\section{Biology of A. hilaralis}

Egg: After successful couplation of male and female A. hilaralis, adult female moths laid whitish color, round shaped eggs in cluster both upper and lower surface of the leaves. Eggs were laid during May to June. Eggs were attached with the leaves by folding the leaves with a sticky substance. After $6.4 \pm 0.24$ days eggs were hatched (Table 1). According to Susanty et al. (2017), A. hilaralis eggs hatching time was 2-3 days in Indonesia. In West Bengal (India), egg hatching period required for 3-4 days (Thapa and Bhandari 1976). The egg hatching period might be differed with the environmental condition like temperature, humidity and precipitation. During the infestation time generally, it prevailed high temperature and humidity with heavy rainfall in Sylhet (Table 2).

Larvae: After hatching the egg, the larvae were feeding kadam leaves voraciously. Tha total larval stage was $12.8 \pm 0.37$ days (Table 1 ). The larval stage of A. hilarali was 12-16 days in Sabah (Malaysia) and 13- 15 days in West Bengal (India) (Thapa 1970, Thapa and Bhandari 1976) which is almost similar in our findings. The larval stage divided into different instar with distinct five molting. The $1^{\text {st }}, 2^{\text {nd }}, 3^{\text {rd }}, 4^{\text {th }}$ and $5^{\text {th }}$ instar larval period were $2.4 \pm 0.24,2.6 \pm 0.24$, $2.4 \pm 0.24,3 \pm 0.45,2.4 \pm 0.24$ days, respectively which was almost close to the result of Susanty et al. (2017). The full grown of caterpillar was around $21.5 \mathrm{~mm}$ to $25.0 \mathrm{~mm}$ in length (Figure 1a). Larval body length of A. hilaralis was found 20.26 $\mathrm{mm}$ in fifth instar in Indonesia (Susanty et al. 2017). 


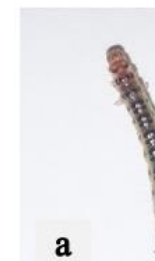

a
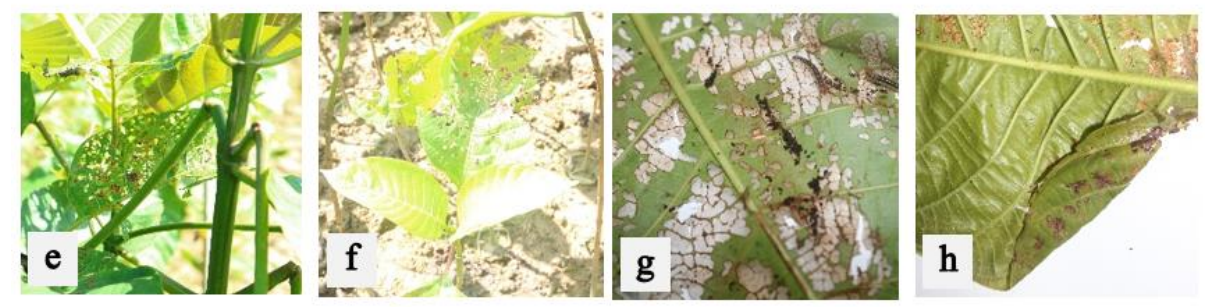

Fig. 1: a) Larval stage of $A$. hilaralis, b) Pupa of $A$. hilaralis, c) Adult (female) of $A$. hilaralis, d) Adult (male) of $A$. hilaralis, e) $A$. hilaralis infestation in A. cadamba leaves, f) $A$. cadamba seedling affected by $A$. hilaralis, g) A. cadamba leaf skeletonized by $A$. hilaralis, h) $A$. cadamba leaf folded by $A$. hilaralis.

Pupa: Pupal stage required around 6.4 \pm 0.60 days which belonged to obtect type, attached with dead leaves or plant parts of kadam (Figure 1b). The brownish color pupa of $A$. hilaralis was around 13 to $14 \mathrm{~mm}$ in length. In West Bengal (India), pupal period took about 5-7 days (Thapa and Bhandari 1976). According to Susanty et al. (2017), the pupal stage lasted for an average of 6.9 days in Indonesia. A cadamba plant is very common in south Asia and southeast Asia (Budi et al. 2015, Krisnawati et al. 2011, Dubey et al. 2011). Might be the climatic condition of the south-east Asia has similar effects on A. hilaralis development in its different region within the similar host.

Table 1. Reproduction biology of $A$. hilaralis under laboratory conditions

\begin{tabular}{lc}
\hline Life cycle stages of $\boldsymbol{A}$. hilaralis & Days (mean $\pm \mathbf{S E})(\mathbf{n}=\mathbf{1 5})$ \\
\hline Egg hatiching period (days) & $6.4 \pm 0.24$ \\
Total larval period & $12.8 \pm 0.37$ \\
First instar larva & $2.4 \pm 0.24$ \\
Second instar larva & $2.6 \pm 0.24$ \\
Third instar larva & $2.4 \pm 0.24$ \\
Fouth instar larva & $3 \pm 0.45$ \\
Fifth instar larva & $2.4 \pm 0.24$ \\
Pupal period larva & $6.4 \pm 0.60$ \\
Adult (female) & $6.8 \pm 0.73$ \\
Adult (male) & $5.6 \pm 0.68$ \\
\hline
\end{tabular}


Adult: A. hilaralis adult was bluish green with yellow orange along the wing costa. Adult males and females had different body sizes that were not significantly different. The average body length of the male adult reached 14-15 $\mathrm{mm}$, while the body length of the female imago was 13-14 $\mathrm{mm}$ (Figure $1 \mathrm{c}-\mathrm{d}$ ). The life span of $A$. hilaralis male adult (5.6 days) was shorter than that of female adult (6.8 days) (Table 1). According to Susanty et al. (2018), the average length of the male imago life span was 4.0 days, whereas the female imago was 6.9 days. Host plant has a great influence on the longevity of the insect. Might be the A cadamba plants has similar effects on the longevity of the A. hilaralis male and females in the same climacteric zone.

Occurrence and damage severity of A. hilaralis in selected area: Results also indicated that there was no significant variation among the locations for number of infested leaves ( $d f=14, p$ value $>0.05$ ) (Figure 2). Only larval stage of $A$. hilaralis chewing the leaves from the tender branches, petiole of the young leaves of saplings (Figure 1e). Just after hatching, larvae started to chew the young tender of leaves. According to Baksha (2000), Younger kadam plants were most heavily infested in Chittagong hilly forest. The survey reported that $A$. hilaralis infestation was recorded in all the three locations of Sylhet region. Highest infestation was recorded in Khadimnagor (7.6 leaves per sapling) compare to South Surma (7.1 leaves per saplings) and Zindabajar (6.8 leaves per saplings) (Figure 2).

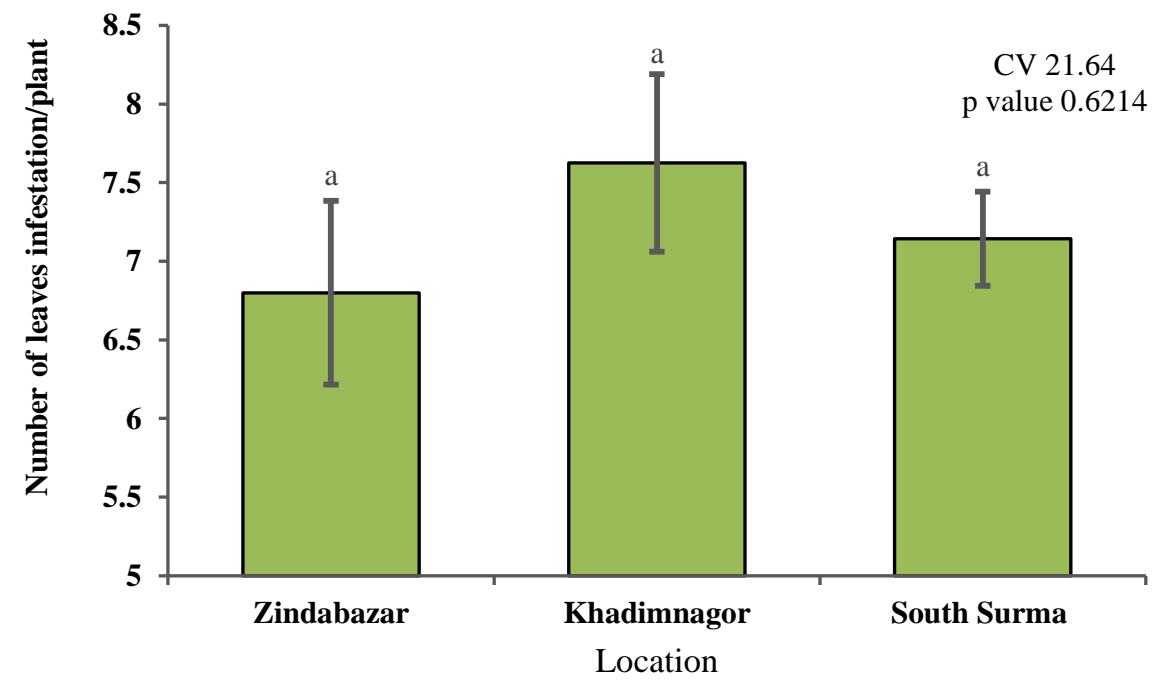

Fig. 2: Level of infestation of A. hilaralis on A. cadamba leaves Temporal mapping of A. hilaralis infestation 
Considering the biology studies and field survey it was confirmed that the $A$. hilaralis severity showed different level in May, 2018 to November, 2018 (Figure 3). Rest of the observation period, it was not found in nurseries of Sylhet region. Almost same results were found in previous study that the peak infestation occurred during August-September in Kadam at evergreen hilly forest of Chittagong (Baksha 2000). The severity differs with the location of the nursery area and the association of alternative host. The severity may also differ with the environmental conditions specially precipitation and temperature. Rainfall may increase the severity and incidence of $A$. hilaralis however sudden flush may reduce the severity of $A$. hilaralis infestation in kadam seedling (Figure 3, Table 2).

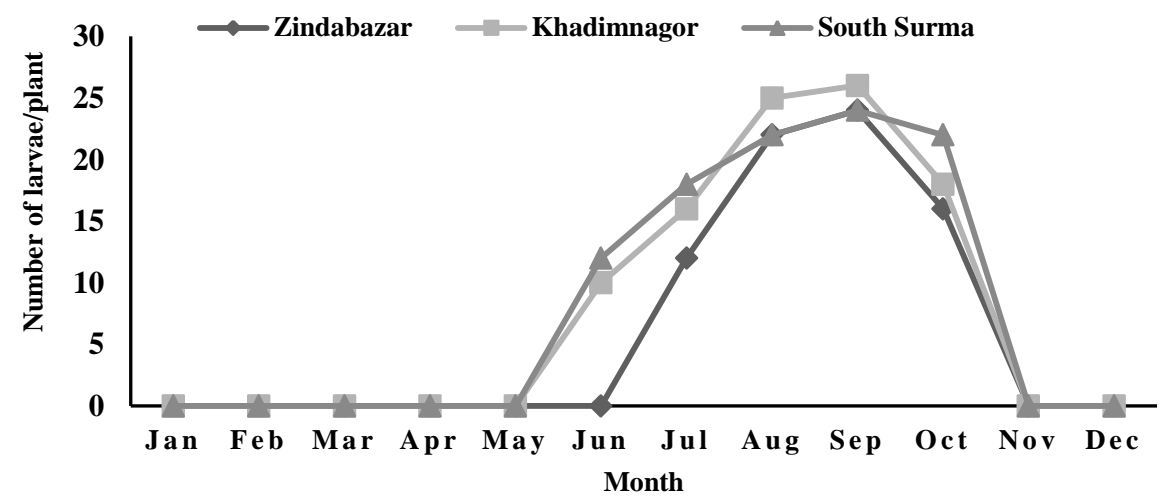

Fig. 3: Infestation time of A. hilaralis on A. cadamba in June, 2018 to May, 2019.

Table 2: The average temperature and rainfall data of 2018-2019 of Sylhet collected from Sylhet Agricultural University meteorological station

\begin{tabular}{lcccc}
\hline Month & \multicolumn{2}{c}{$\mathbf{2 0 1 8}$} & \multicolumn{2}{c}{$\mathbf{2 0 1 9}$} \\
\cline { 2 - 5 } & $\begin{array}{c}\text { Temperature } \\
\text { (Celsius) }\end{array}$ & $\begin{array}{c}\text { Rainfall } \\
\text { (mm) }\end{array}$ & $\begin{array}{c}\text { Temperature } \\
\text { (Celsius) }\end{array}$ & $\begin{array}{c}\text { Rainfall } \\
\text { (mm) }\end{array}$ \\
\hline January & 24.8 & 0 & 23.8 & 0 \\
February & 28.5 & 39 & 27.4 & 137 \\
March & 31.4 & 95 & 29.2 & 470 \\
April & 30.9 & 393 & 31.2 & 687 \\
May & 30 & 505 & 30.8 & 556 \\
June & 32.5 & 801 & 32 & 919 \\
July & 34.1 & 690 & 34 & 712 \\
August & 33.6 & 506 & 33.4 & 876 \\
September & 32.2 & 373 & 31.8 & 484 \\
October & 31.2 & 103 & 31.4 & 301 \\
November & 29.6 & 40 & 27.9 & 13 \\
December & 27.1 & 29 & 24.1 & 54 \\
\hline
\end{tabular}




\section{CONCLUSION}

Considering the recent status and occurrence of $A$. hilaralis in Sylhet district, there is an urgent need for eco-friendly management of A. hilaralis. If this devastating pest is not managed as soon as possible, there would be a possibility of the outbreak of this pest which subsequently hinder kadam plantation in evergreen hilly forest and the low laying areas of Sylhet. Consequently, great environmental loss will be happening in near future.

Acknowledgment: We acknowledge the Department of Entomology for their technical supports and partial funding.

\section{LITERATURE CITED}

ALAM, M. A., RAUSHANARA, A., NUSRAT, S., MOSTAFIZUR, R., MUNTASIR, M. M., LUTFUN, N. and SATYAJIT, D.S. 2008. Antidiarrhoeal property of the hydroethanolic extract of the flowering tops of Anthocephalus cadamba. Braz. J. Pharm. 18: 155-159.

ALAM, M.A., SUBHAN, N., CHOWDHURY, S.A., AWAL, M.A., MOSTOFA, M., RASHID, M.A. and SARKER, S.D. 2011. Anthocephalus cadamba (Roxb.) Miq., Rubiaceae, extract shows hypoglycemic effect and eases oxidative stress in alloxan-induced diabetic rats. Braz. J. Pharm. 21(1):155-164.

BAKSHA, M.W. 2000. Biology, ecology and management of kadam defoliator, Arthroschista hilaralis Walker (Pyralidae: Lepidoptera) in Bangladesh. Bangladesh J. For. Sci. 29(2):133-136.

BANGLAPEDIA. 2015. Timber Tree (National Encyclopedia of Bangladesh). Ministry of planning. People's Repub. Bangladesh, Dhaka.

(http://en.banglapedia.org/index.php?title=Forest_and_Forestry)

BFD. 2018. Bangladesh Sustainable Forest and Livelihood (SUFAL) Project. Bangladesh Forest Department. Government of Peoples' Republic of Bangladesh, Dhaka, Bangladesh. pp. 21-22.

BUDI, B., DEDE, J.S., DON, K.L. and YONG, S.K. 2015. Effect of initial morphology on field performance in white jabon seedlings at Bogor, Indonesia. For. Sci. Tech. 11(4): 206-211.

DUBEY, A., NAYAK, S. and GOUPALE, D. C. 2011. Anthocephalus cadamba: A review. Pharmacognosy J. 2(18): 71-76.

GAUTAM, R., IRCHHAIYA, R. and SWARNAKAR, R. 2012. Anthocephalus cadamba (Roxb.): an overview. Int. J. Pharm. Res. and Dev. 4(4): 169-173.

GOGOI, K., DAS, R. and YONZONE, R. 2015. Orchids of Assam, North East India-An annotated checklist. Int. J. Pharm. \& Life Scie. 6(1): 4123-4156.

INTARI, S.E. and NATAWIRIA, D. 1973. White grubs in forest tree nurseries and young plantations. 167. p.2.

KRISNAWATI, H., KALliO, M. and KANNINEN, M. 2011. Anthocephalus cadamba Miq.: ecology, silviculture and productivity. CIFOR; Bogor Indonesia. pp.1-3. 
SELANDER, J. 1990. Forest pests and diseases of plantation trees in South Kalimantan (Indonesia). Technical Report (8). p. 22.

SURATMO, F.G. 1987. Current potentially dangerous forest pests in Indonesia. Biotrop Special Pub. (Indonesia). Pp. 91-95.

SUSANTY, S.C., HANEDA, N.F. and MANSUR, I. 2017. Life cycle of Arthroschista hilaralis (Lepidoptera: Pyralidae) on Jabon trees (Anthocephalus cadamba Miq). Serangga. 22(2):115133.

TANGKETASIK, J. 1987. Some insect pest on trial plantation of PT ITCI, Kenangan, Balikpapan, East Kalimantan (Indonesia). Wanatrop. 2(1): 41-53.

THAPA, R.S. 1970. Bionomics and control of Laran defoliator, Margaronia hilaralis Wkr.(Lepidoptera: Pyralidae). Malayan For. 33(1):55-62.

THAPA, R.S. and BHANDARI, R.S. 1976. Biology, ecology and control of Kadam defoliator, Arthroschista hilaralis Walk.(Lepidoptera: Pyralidae) in plantation in West Bengal. Indian For. 102(6):333-401.

UTAMI, S., TRIWIDODO, H., PUDJIANTO, P., RAUF, A. and HANEDA, N.F. 2018. Serangan Arthroschista hilaralis Walk. (Lepidoptera: Pyralidae) pada tegakan jabon (Neolamarckia cadamba [Roxb.] Bosser) di Sumatera Selatan. J. Entomol. Indo. 15(1):1.

(Manuscript received on 19 October, 2020 revised on 20 February, 2021) 